\title{
民族 衞生
}

第 26 巻 昭和 35 年 7 月 第 4 号

原著

Fumiyoshi Yanagisawa, Kyomaro TANAKa, Noriko SUYAma, Kimiko Seki, Takuji Hata and Yoshio MatsuURa: The Results of a Mass-Examination of Urine in a Farm Village (Murakami-mura, Nagano Prefecture)

\section{一農村 (長野県村上村)の集団検尿成績}

東京医科菌科大学医学部農村厚生医学研究施設（主任 柳沢交德教援） 柳沢文徳・田中香璴・陶山のり子・関公子 東京都立蕧生研究所臨床検査科（科長 柳沢文正博士）

畑卓次・松浦義男

\section{緒言}

農村の潜在性慢性疾患の摘発のために，集 団検尿が如何なる意義を有するかを検討する 目的の第一段階として，農村住民の蛋白尿， 糖尿の出現頻度の研究を開始し, 既に数報1)2) 3）に亘つて報告してきた。今回は昭和 33 年 8 月中旬に長野県更科郡村上村に於いて実施し た成績を玆に報告する。

\section{実 験 成 績}

調査対象村：長野県千曲川沿岸の長野県更 科郡村上村であつて, 本村の調查時の人口(昭 和 33 年 8 月 1 日現在, $0 \sim 5$ 才郡は一部認査 未了）は 3,055 名（男子 1,520 名，女子 1,535 名）であつた。本村の農業は稲作を中心とし て扣り，二毛作田である。かつては養虫がか なり多かつたが, 漸次減少し，それに代つて
換金が容易な果樹園（主に林檎）経営及び 花栽培が行われてきて扔る。同村の保健衛 生問題に対する関心はこの数年間で高め られてきて扣り，各種の集団検診の受検率 も高まつてきて扔る．本農村の調査地の一般 概要は別報として報告する予定であるが，こ

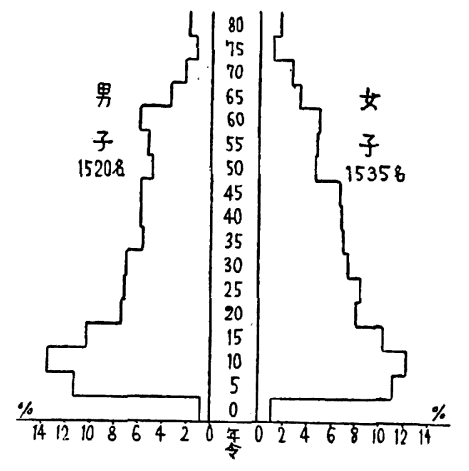

第 1 图男 - 女別年令桠成百分率 
こに本調査の基礎となる人口構成（5才区分） を第 1 図として示して拈く。

受検者：検尿は全村民を対象としたが，血 王測定は 30 才以上とした。

集団検尿，集団血圧測定の方法：すでに柳 沢 1), 松浦 2）によつて詳述されているので, 省略するが，対象者を 1 日で尿蛋白・尿糖・ 尿ウロビリノーゲンを実施した。

受検率：集団検査に際してはその受検率が 問題になる。集団検尿の受検率に関する成績

第 1 表 男子年令区分別の受検率，蛋白， 糖及びウロビリノーゲンの陽性者数

\begin{tabular}{|c|c|c|c|c|c|c|c|c|c|c|}
\hline \multirow{2}{*}{$\begin{array}{ll}\text { 年 } & \text { 今 } \\
\text { 巨分 }\end{array}$} & \multirow{2}{*}{10} & \multirow{2}{*}{ 受湌当 (\%) } & \multicolumn{3}{|c|}{ 疍 } & \multicolumn{4}{|c|}{ 䅯 } & \multirow{2}{*}{$\frac{50 \kappa^{\prime} \| 1-40}{+(\%)}$} \\
\hline & & & \pm & \pm & 部 & & & $t$ & st & \\
\hline $0 \sim 4$ & 13 & & & & 0 & & & & & $0(0)$ \\
\hline $5 \sim 9$ & 177 & & 1 & 3 & 4 & & & & & (3) \\
\hline $10-14$ & 204 & & 3 & 2 & 5 & & & 1 & 1 & $8(4.8)$ \\
\hline 19 & 157 & & 3 & & 3 & & & & 0 & $12(12.5)$ \\
\hline $10-24$ & 116 & & 1 & & 1 & 7 & & & 0 & $9(14.8)$ \\
\hline 29 & 113 & & 2 & 1 & 3 & & & & 0 & $15(21.1)$ \\
\hline $30-34$ & 107 & & 1 & & 1 & 1 & & & 1 & $8(11.1)$ \\
\hline $35 \sim 39$ & 83 & & & & 0 & & & & 1 & $6(9.4)$ \\
\hline $40-44$ & 87 & & 1 & 1 & 2 & 1 & 1 & & 2 & $15(19.6)$ \\
\hline $45-49$ & 87 & & 1 & 4 & 5 & & 2 & & 2 & $16(23.9)$ \\
\hline $50-54$ & 73 & & 1 & 1 & 2 & & 1 & & 1 & $14(24.0$ \\
\hline $55-59$ & 78 & & 2 & 3 & 5 & 1 & 1 & & 2 & $14(23.0)$ \\
\hline $60-64$ & 90 & .74.4) & 3 & 4 & 7 & & & & 0 & $10(14.9)$ \\
\hline $65-$ & 56 & 80.4 & 3 & 8 & 11 & 2 & & & 2 & $9(20.0)$ \\
\hline $70-?$ & 34 & 58.2) & 2 & 6 & 8 & & & & 0 & $2(100)$ \\
\hline $75 \sim 79$ & 20 & $70.0)$ & 3 & 4 & 7 & & & & 0 & $9(64.2)$ \\
\hline $80-85$ & 18 & $13(72.2)$ & 4 & 3 & 7 & & & & 0 & $4(30.7)$ \\
\hline & & & & & & & & & 0 & $0(0)$ \\
\hline $90 \sim$ & 1 & 100.0) & & 1 & 1 & 15 & & & & I $(100,0)$ \\
\hline 不明 & 5 & & & & 0 & & & & 0 & $1(20.0)$ \\
\hline t & 1520 & 13.4) & 31 & 41 & 72 & 18 & 6 & & 14 & $135(12.1)$ \\
\hline
\end{tabular}

第 2 表 女子・年令区分別の受検率, 蛋 白, 糖及びウロビリノーゲンの陽性 表数

\begin{tabular}{|c|c|c|c|c|c|c|c|c|c|}
\hline \multirow{2}{*}{ 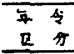 } & \multirow{2}{*}{ 人 } & \multirow{2}{*}{ 岂校表(\%) } & \multicolumn{3}{|c|}{ 疍 白 } & \multicolumn{3}{|c|}{ 樚 } & \multirow{2}{*}{$\frac{f(\%)}{t(\%)}$} \\
\hline & & & \pm & $t$ & $\$ 4$ & & $t$ & At & \\
\hline $0 \sim 4$ & 18 & & & & & & & & $0(0)$ \\
\hline & 175 & & & 3 & & & 1 & 1 & $11(7.9)$ \\
\hline & 174 & & 2 & 1 & 3 & & 2 & 2 & $11(11.3)$ \\
\hline & 151 & & 2 & 3 & & & & & $10(10.3)$ \\
\hline & 128 & & 1 & 2 & 3 & & & & $9(12.9)$ \\
\hline & 143 & 109 & & 2 & 2 & 1 & 2 & & $14(12.8)$ \\
\hline & 118 & & 2 & 1 & 3 & 1 & & & $17(18.1)$ \\
\hline & 100 & & & 4 & 4 & & & & $16(19.5)$ \\
\hline & 92 & & 1 & 2 & 3 & 1 & & & g. (1).4) \\
\hline & 88 & & 1 & 1 & & & & & ( 5.1 \\
\hline & 67 & & 1 & 5 & 6 & 2 & 1 & s & $6(10.7$ \\
\hline & 65 & & & 4 & 4 & 2 & 1 & 3 & $3(5.5$ \\
\hline & 55 & & & 8 & 8 & & & 0 & $7(15.9$ \\
\hline & 50 & & 1 & 11 & 13 & & 2 & & $4(9.1$ \\
\hline & 40 & & 1 & 6 & & & & 0 & 6.4 \\
\hline & 38 & & 2 & 8 & 10 & & 2 & & $8(29.6)$ \\
\hline & 19 & & 2 & 3 & & & & & $3(42.9$ \\
\hline & 8 & & 2 & 1 & 3 & & & 0 & 1620.0 \\
\hline & 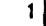 & & & 1 & 1 & & & & $0(0)$ \\
\hline 不 明 & 5. & & & & 0 & & & 0 & 01 \\
\hline It & 1535 & $1.178(76.7)$ & 18 & 67 & & 7 & 11 & & $135(11.5)$ \\
\hline
\end{tabular}

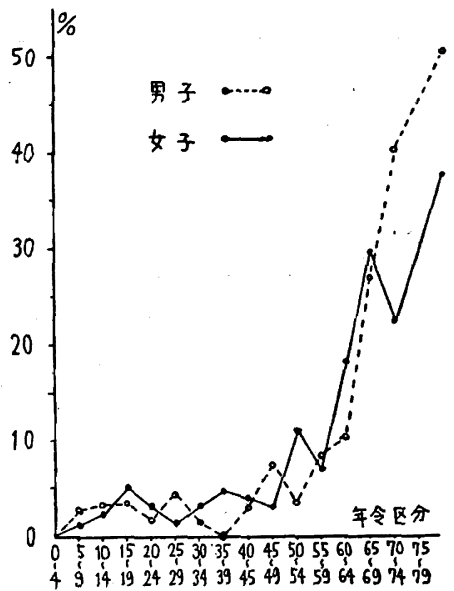

第 2 图年令区分別・男女別蛋白 陽性率の状況

を第 1 表，第 2 表に示して括く.すなわち男子 の受検率は 73.4\%，女子 76.7\% で，全村民に 対し 75.1\% という受検率であり，かなり高率 であるといえる．5才年令区分でみると，男 子では 100 58.8\%，女子では 100 36.8\% の 範囲にあつて，大体平均した受検率であつた。

尿蛋白陽性状況： 尿蛋白の陽性者の年令階 級別・性別にみた状況は第 1 表，第 2 表の如 くである，受検者に対する蛋白陽性率を図示 したのが第 2 図である。男子の陽性率は 6.45 \%，女子 $7.23 \%$ であつて，男女 合計は 2.294 名のうち 157 名であるから，6.84\% となる。 いずれにしても女子の方が陽性率が高い，年 令階級別・男女別の陽性率をみると，大体 40 〜4才群までは 5\% 以下であるが，50〜54 才 群より陽性率は上昇して，65～69才群では 30 \% 内外になるという移行を示している，即ち 年令別にみると，尿蛋白陽性は本村では 45 才 以上の年令より問題になつてくるということ が明らかになつた。な特女子では高年令層は 女子の方が早く陽性率が高くなり，年令が 70 才以上になると男子の方が多いという結果に なつて报る、いま 50 才以上の年令の蛋白陽性 率は男子受検者 279 名のうち陽性 48 名（17.2 $\%)$ ，女子受検者 270 名のうち 53 名 (19.6\%) 
となつて，女子の方が高率である.

尿糖陽性状況：集団检尿時に扔ける尿糖陽 性者は男子 14 名 $(1.25 \%)$, 女子 18 名 $(1.52 \%)$ であつた。柳沢 1) の成績にある如く，陽性者 のうち（士）は多くの場合（一）になること が多く，本調査に際しても陽性者につき再検 查を実施した。本検査はニーランデル法及び シノテストを用いて判定した。ニーランデル 法で陽性のものは，すべてシノテストでも陽 性を示し，その成績の相違を示さなかつた。 ニーランデル法では反応が (土) の判定を下さ れる場合が, シノテストでは陰性に認められ， 反覆検査でニーランデル法で陰性になること が多く，このことは松浦 2)も検討したが将来 に执いてはシノテストの方が実験方法として は簡易であるから，集団検尿ではシノテスト をるつて尿糖の screening 法となりうること と考えられる. 再検査の成績は第 3 表に示す.

第 3 表 集団検尿糖陽性者に対する 再検査成績

\begin{tabular}{|c|c|c|c|c|c|}
\hline 性别 & 局性 & 桌田板查 & & 㮎 & 坴 \\
\hline 性漹 & $E \pi$ & 䧄性者数 & 觉榙者 & $t$ & $=$ \\
\hline \multirow{2}{*}{$\begin{array}{l}\text { 男 } \\
\text { 子 }\end{array}$} & \pm & 8 & 7 & 1 & 6 \\
\hline & + & 6 & 5 & 4 & 2 \\
\hline \multirow{2}{*}{$\begin{array}{l}女 \\
\text { 子 }\end{array}$} & \pm & 7 & 5 & & 5 \\
\hline & + & 11 & 10 & 6 & 4 \\
\hline
\end{tabular}

すなわち集団検尿で士であつた 12 名の 5ち 1 名（男子）のみ陽性であり，十で あつたものの再検査 受検者 15 名のうち 10 名が再検査で陽性であつて, 他は陰 性になつた。この陰性者につき更に検査 をしたが，いづれも陰性に終つている。 この成績より再検査を受検しない者もあ るので，全集団検尿受検者に対する糖尿 陽性者と云えぬが, 男子では 5 名, 女子 6 名という結果を得た。すなわち男子全 受検者に対し $0.44 \%$ ，女子 $0.50 \%$ とい 結果を得た。

集団検尿糖陽性者に対する再検査受検 者に対して Folin-Wu 法による血糖值の 測定を実施した。採血は朝食後 60〜90
第 4 表 再検査 28 名の血糖値 $\mathrm{mg} / \mathrm{dl}$

\begin{tabular}{|c|c|c|c|c|}
\hline 14:11 & 男 & 子 & 女 & 子 \\
\hline 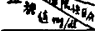 & - & + & - & $t$ \\
\hline $\begin{array}{l}80-10 F \\
80-100\end{array}$ & $\begin{array}{l}1 \\
5\end{array}$ & & $\begin{array}{l}2 \\
4\end{array}$ & \\
\hline $100 \sim 120$ & 2 & 2 & 3 & 1 \\
\hline $120-140$ & & 1 & & 2 \\
\hline $160 \sim 180$ & & & & \\
\hline $180-200$ & & & & 1 \\
\hline 200 以上 & & 1 & & 2 \\
\hline 計 & 8 & 5 & 9 & $\frac{2}{6}$ \\
\hline
\end{tabular}

分の範囲である. その成績を第 4 表として示 す。尿桾陽性者の 5ち $200 \mathrm{mg} / \mathrm{dl}$ 以上という ものは 3 名であつて, それほど重症の糖尿病 そ称するるのはなかつた。

尿ウロビリノーゲン：参考のためにウロビ リノーゲンの陽性状沉をみたが，本実験は判 定上に多少の問題が残されているが，かなり 陽性率は高い。

血圧の測定：な招本㭘尿調査と同時に血圧 の測定も併せ実施したので，その成績を簡単 に記載しておく，血圧の測定は松浦の静岡県 の一農村に実施した際と同様である. 対象年 令は 30 才以上について実施した。その性別・ 年令別の最高血压の分布を第 5 表として示す。

本村の高血圧は 40 才頃より認められ, 受検 者男子 378 名のうち最高血圧 $140 \mathrm{mmHg}$ 以上

第 5 表 性別・年令別の最高血圧值 $(\mathrm{mmHg})$ の分布

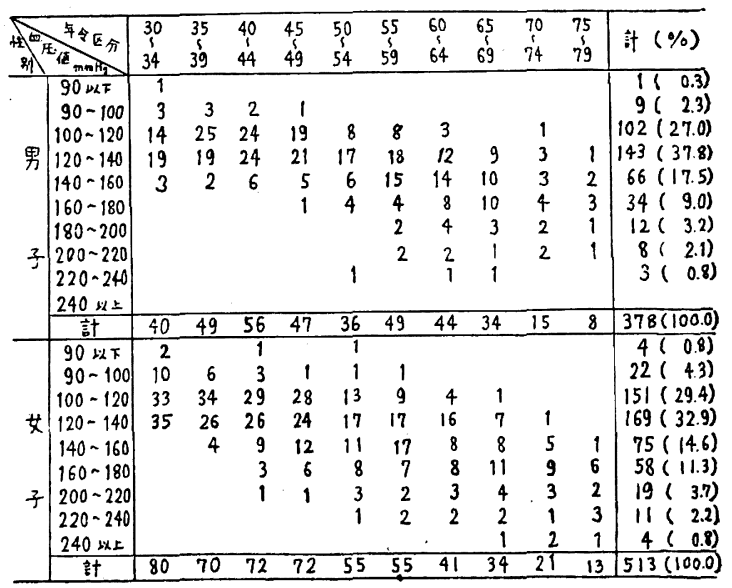




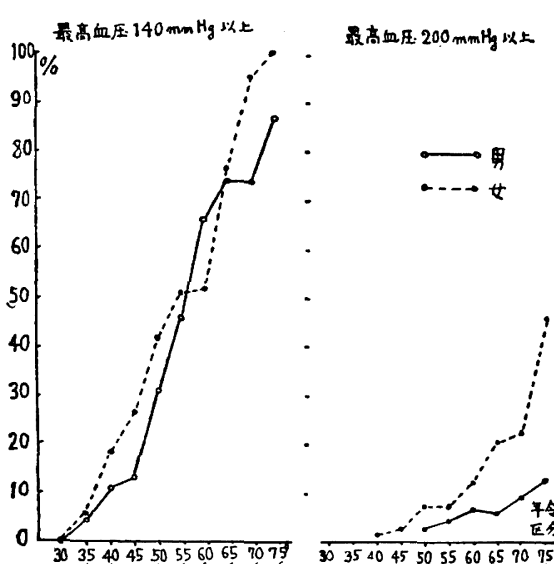

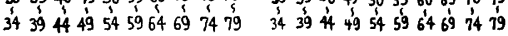

第3 图最高血圧 $140 \mathrm{mmHg}$ 及び $200 \mathrm{mmHg}$ 以上の出現率の年令白分布

が $32.5 \%$ ，女子 513 名のうち $32.6 \%$ で，200 $\mathrm{mmHg}$ 以上は男子 $2.9 \%$ ，女子 $6.6 \%$ であつ て, 女子の方が高血圧者が多いという結果に なつて扮る。年令的に $140 \mathrm{mmHg}$ 以上の血圧 者の出現率を第 3 図として示ずと，男子では 45 才以上, 女子では 40 才以上ょり上䄯の傾 向を示し, 男女共 55 才以上では $50 \%$ を占め ている、また $200 \mathrm{mmHg}$ 以上の高血圧症の出 現頻度は, 男子は少ないが, 女子の方がかな り高率に認められた。

最低血圧については $90 \mathrm{mmHg}$ 以上の出現 率を年令区分別に示し たのが第 6 表である. 最低血圧でる最高血圧 と同様に男女共 50 才 以上になつてかなり多 くなつている。

本村では女子の方が 高血圧の出現が年令的 に早く，且つ男子ょり多いという結果を得た。

\section{結論並びに考按}

農村地域は都市と異なり，かなりの潜在性 の慢性疾患が存在していることは, 教室両角 5)によつても指摘したが, 藤井6), 若月7)等
によつて農夫症という病名の下にこれらの点 について多くの吟味がなされて括る．農村の これらの疾病に関する発見は，農村の保健衛 生上極めて重要であることは云うまですない。

前述のごとく長野県の一農村に和ける集団 検尿（蛋白・糖）を実施した成績によつても， 著者等の実施するる集団検尿法を採用すれば， 短期間に一農村全住民の 集団検尿が 実施し5 ることは本例に扰いても再確認をしたわけで 安る。

農村に括ける潜在性慢性疾患の摘発は，今 迄しばしば述べてきた如く，種々の方法があ るが，尿をと扤して一部の潜在性に存在する 蛋白尿疾患, 糖尿病を簡単な尿検査で screening することができることも再び認めた。

ここに従来検討してきた数力村の 40 才以上 の尿蛋白出現者の 調査成績 1)2３）4）を総括し てみると第 7 表の如くであつて，農村によつ てもその尿蛋白の陽性率に相違が認められる。

第 7 表 集団検尿による尿蛋白陽性状況

\begin{tabular}{|c|c|c|c|}
\hline 調 查村 & 受検者 & 陽性者 & 作 考 \\
\hline 长野县村上村 & 851 & $117(137 \%)$ & \\
\hline 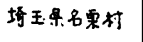 & 993 & $38(3.8 \%)$ & 林村 \\
\hline 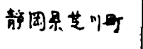 & 397 & $99(24.9 \%)$ & 橡子都荍 \\
\hline 長野余使阳村 & 1150 & $186(12.7 \%)$ & 算高冷地 \\
\hline 静因尔井川村 & 69 & $12(17.4 \%)$ & 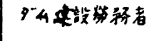 \\
\hline
\end{tabular}

埼玉県 名栗村が 少なく，僅かに 3.8\% という 尿蛋白陽性率の成績であるに反し, 静岡県の 芝川町稲子部落では $24.9 \%$ という高率である。 長野県の調査村と同一地方に山る傍陽村では $12.7 \%$ であつて, 本村とでは略々同様な陽性 率であることが判明した。普通の稲作及び畑 を中心とする農耕農村の蛋白陽性率は $10 \%$ 内 外であるという傾向があるものと考えられる。 また年令的な観察では 40 才以上を対象とする ことによつて著者等の目的が達しうることも， 略々判明したものと考兵る次第である、今後 の研究に拈いては, 蛋白尿の原因について詳 
細なる解析をする段階に至つたと考え，蛋白 尿，糖尿の成因に関する調査研究を実施する 予定である。

また尿糖陽性者は本村に括いても明らかに 糖尿病として認められて呿つた者は，僅かに 1 名にすきぎ，この集団検尿によつて始めて 糖尿病であることが screening されたわけで ある。

血圧の測定では本村は高血圧者が多く，男 女共に 40 才頃より最高血圧が上梨するが，そ の場合女子の方が男子より早く血圧の上昇が 認められた。

本村の高血圧が多いという因子は更に各方 面より解析しなければ判明しないが，同村の 一般状況よりみて, 福田 ${ }^{8)}$ が秋田県の血圧調 査で指摘した如く，本村でも過重労働が大き な因子になつているものと考兄られる。

また年令別にみて高血圧の 出現と尿蛋白陽 性の出現と同一年令に拈いて上䄯することが みられた。

以上の成績を総括すると

1. 調査対象村の人口は 3,055 名（男子 1,520 名, 女子 1,535 名) で山つて, その全人口に 対する 集団検尿の 受検者は 2,294 名で受検率 は75.1\%（男子 73.4\%，女子 76.7\%）であつ た。かなり受検率は良好と認めた。

2. 集団検尿によつて 尿蛋白陽性の発現率は
男子 $6.45 \%$ ，女子 $7.23 \%$ であつた。

3. 集団検尿によつて，尿糖陽性の発見率は 男子 $1.25 \%$ ，女子 $1.52 \%$ であり，それより尿 糖陽性者の再検査及び血桾值の 測定によつて 糖尿病と推定される者男子 5 名，女子 6 名を 発見した。

4. 血圧の測定では最高血圧が $140 \mathrm{mmHg}$ 以 上が 30 才以上に招いて男子では受検者 378 名 のうち 119 名で $31.5 \%$ ，女子では受検者 513 名のうち 174 名で $33.9 \%$ で山つた。

本研究は昭和 33 年度文部省科学研究費（個 人研究柳沢文德）によるところ大である。なお 本調査に際し，長野県篠ノ井保健所々長及び同 職員，並びに村上村役場職員の方々に御配虑を いたたいたことを厚く感謝致します。また東京 医科菌科大学農村医学研究部員の学生諸君の協 力を得たことをここに記して謝意を表す。

\section{主 要 文 献}

1) 柳沢他：日本语生学雑誌, 13, 510 (1958)

2) 松浦：扣茶の水医学雑誌, 8, 364 (1960)

3）柳沢：民族䛔生, 25, 757 (1959)

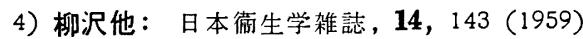

5) 两角: 農村医学, 8, 116,137, 155 (昭和34年)

6) 若月他：農村医学, 6, (3) (昭和 33 年)

7) 藤井他：農村医学北海道地方誌, 4, (1)（昭 和 31 年)

8) 福田：診断と治療， 43，104（昭和 30 年） 
The Results of a Mass-Examination of Urine in a Farm Village

(Murakami-mura, Nagano Prefecture)

\section{By}

*Fumiyoshi Yanagisawa, Kyomaro Tanaka, Noriko suyama, Kimiko SEKI, *Takuji Hata and Yoshio MatsuURa

A mass examination of urine (protein and sugar) was made in a farm village. (Murakami-mura, Sarashina-gun Nagano-Prefecture).

1. The population of the village was 3,055 , including 1,520 males and 1,535 females. Those who took the examination were 2,294 , and the rate was as high as $75.1 \%$ (73.4\% in the male and $76.7 \%$ in the female).

2. The rate of discovery of albuminuria was $6.45 \%$ in the male and $7.23 \%$ in thefemale.

3. The rate of discovery of glycosuria was $1.25 \%$ in the male and $1.52 \%$ in the female. Five men and six women were assumed to have diabetes by the reexamination of the urine and measurement of the blood sugar.

4. As for blood pressure, the maximum blood pressure was higher than $140 \mathrm{~mm} \mathrm{Hg}$. in $119(31.5 \%)$ of 378 examined men above the age of 30, and in 174 (33.9\%) of 513 . examined women above the same age.

$$
\left(\begin{array}{c}
* \text { From the Institute of Medical Research for Rural Welfare, } \\
\text { Tokyo Medical and Dental University, Tokyo } \\
* * \text { From the Tokyo-to Laboratory for Medical Siences, Tokyo }
\end{array}\right)
$$

Center of Gravity in Japanese with Special Reference to Physical Development

$$
\text { By }
$$

Toshiro Ishiko, Junko Yamakawa, Setsuko Mryauchi

The center of gravity is deeply related to the balance and motion of the body. The change of the center of gravity accompanying physical development an interesting problem to those who study physiology, kinesiology and physical education.

Akita, thirty years, ago, measured the center of gravity in Japanese, but his results cannot be applied to Japanese of today. So the authors studied the center of gravity of Japanese in supine position simultaneously with the anthropometric measurements and following results were obtained.

1. Total numbers of subjects were amounted to 2260 including $1 \sim 20$ ages of both sexes.

2. The height and the relative height of the center of gravity are tabulated as. 